\title{
Structural plasticity of the nuclear envelope and the endoplasmic reticulum
}

\author{
E. V. Sheval, Y. R. Musinova \\ A. N. Belozersky Institute of Physico-Chemical Biology, \\ M. V. Lomonosov Moscow State University \\ Leninskie gory, house 1, building 40, Moscow, Russian Federation, 119992 \\ sheval_e@belozersky.msu.ru
}

\begin{abstract}
The nuclear envelope is a double membrane structure, continuous with endoplasmic reticulum, and the morphological organization of both these structures is quite conservative. However, nuclear envelope and endoplasmic reticulum demonstrate distinct structural plasticity, i. e., based on common organization, cells may form various non-canonical membrane structures that are observed only in specialized types of cells or appear in different pathologies. In this review, we will discuss the mechanisms of the biogenesis of such non-canonical structures, and the possible role of this plasticity in the development of pathological processes.
\end{abstract}

Keywords: nuclear envelope, endoplasmic reticulum, structural plasticity.

Introduction. The nuclear envelope (NE) is a double lipid bilayer consisting of the outer nuclear membrane (ONM), continuous with endoplasmic reticulum (ER), and inner nuclear membrane (INM). The morphological organization of NE and ER is quite conservative but based on this organization, cells may form various noncanonical membrane structures observed only in specialized types of cells or appearing in different pathologies (Figure). Recent studies have led to significant advances in the understanding of the biogenesis of such non-canonical structures, most notably in studies analyzing the overexpression of different proteins of NE and ER.

The nuclear envelope. The NE is formed by INM and ONM, which are separated by a periplasmic space. Although ONM is contiguous with ER, INM contains at least 100 unique components specific to this membrane [1-3].

Huge nuclear pore complexes (NPCs) are localized in perforations formed in NE membranes. NPCs are composed of multiple copies of $\sim 30$ distinct proteins

(C) Institute of Molecular Biology and Genetics, NAS of Ukraine, 2014 (nucleoporins) arranged with eightfold radial symmetry, leading to an assembly of 500-1000 proteins with an estimated mass of $\sim 125 \mathrm{MDa}$ in vertebrates [4]. Recently, NPCs with ninefold symmetry that are found occasionally among the more typical eightfold symmetrical structures were described [5]. The yeast NPC organization was extensively investigated, and the molecular architecture was described using immuno-electron microscopy [6]. Altered expression of some nucleoporins affects both the nuclear size and shape. For example, deletion of yeast proteins Mlp1p and Mlp2p, structural components of the NPC basket, led to increased NPC mobility and clustering and the formation of misshapen nuclei that frequently exhibited NE blebs [7]. Nup136 overexpression in Arabidopsis thaliana increased nuclear size and elongation, whereas reduced Nup136 expression resulted in smaller, more spherical nuclei $[8,9]$.

NPCs control nuclear-cytoplasmic traffic. In some cases, NPCs do not provide a reliable separation of the nucleus and cytoplasm, e. g., pore permeability increases during the development of viral infections, leading to the displacement of nuclear proteins into the cytoplasm and vice versa $[10,11]$. It has also been shown 


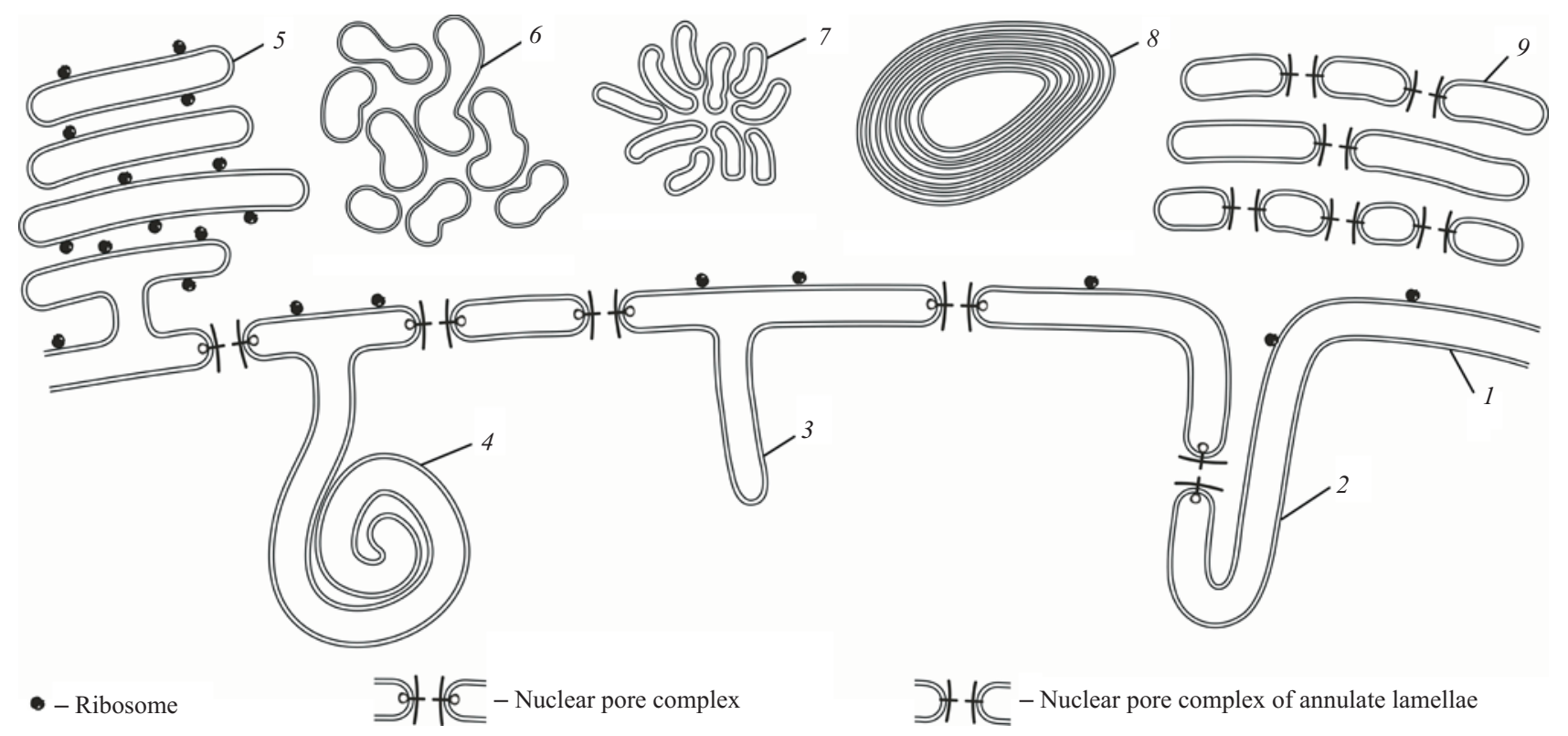

Structural complex of the nuclear envelope and the endoplasmic reticulum: 1 - nuclear envelope; 2 - invagination of the nuclear envelope; 3 - protrusion of the inner nuclear membrane; 4 - nucleoplasmic membrane structure (nucleoplasmic reticulum); 5 - rough endoplasmic reticulum; 6 smooth endoplasmic reticulum; 7 - aggregate of membrane tubules; 8 - organized smooth endoplasmic reticulum (OSER); 9 - annulate lamellae (AL)

that pore permeability may increase during aging as a result of the destruction of long-lived nucleoporins [12].

Typically, traffic via NPCs is considered as the only way for cargoes to be transferred between the nucleus and the cytoplasm. However, some viruses are able to bypass NPCs in membrane vesicles that bud from the INM and merge with the ONM $[13,14]$. A similar nuclear export process was recently described for large ribonucleoprotein particles involved in Wnt signaling in Drosophila larvae muscle cells [15]. The extent of the use of this nuclear export mechanism is currently unknown.

Plasticity of the NE. INM is adjacent to a thin (15$20 \mathrm{~nm}$ ) protein layer, the nuclear lamina, which plays an important role in the formation and maintenance of the structural integrity of the cell nucleus. The lamina is composed of A- and B-type lamins, which belong to the type $\mathrm{V}$ intermediate filament family. Biochemical studies have shown that purified lamins can assemble in vitro into filamentous structures [16-18]. The mechanisms of the formation of the nuclear lamina in vivo are not well known.

Cells are capable of existing without lamin A, as it is known not to be expressed in embryonic cells [19]. Btype lamins are found in all cells; however studies using mice with knockout of both B-type lamins (B1 and B2) indicates the possibility that cells may exist without these proteins $[20,21]$.

An important parameter is the stoichiometry of Atype and B-type lamins. In liver and brain, A-type lamins have relatively low expression levels, whereas A-type lamins are increased in heart and muscle to withstand mechanical stresses and to limit potential disruption of chromatin [22]. Differentiation of embryonic stem cells was accompanied by increased level of A/C-type lamins $[23,24]$. Downregulation of A-type lamins and concomitant irregularities in nuclear shape are exhibited in many cancers. For example, A-type lamins show low or no expression in small cell lung cancer cells [2527 ]. In colon cancers [28], gastric cancers [29, 30], breast cancers [31, 32] and diffuse large B-cell lymphomas [33], the A-type lamin expression is also greatly reduced and correlates with increased recurrence of disease and a poor prognosis.

Lamin B1 overexpression leads to excessive production of the NE [34, 35], resulting in numerous invaginations. NE in such cells contains fewer nuclear pores [35] than in control cells. It appears that the excess NE is not a compensatory response but rather a consequence of lamin self-assembly, which is similar to self-assembly in vitro [16-18]. The formation of invaginations may be a consequence of excess surface area relative to a constant 
nuclear volume and therefore a consequence purely driven by geometry. It should be stressed that the ER system is very poorly developed in cells overexpressing lamin $\mathrm{B} 1$, indicating that the NE growth is due to the ER membrane [35].

The overexpression of B-type lamin might be the cause of some diseases. For example, overexpression of the Drosophila ortholog of lamin B1 (Dm0) leads to neuronal cell death and a reduced life span [36]. It is also known that duplication of LMNB1 leads to neuronal demyelination and the development of autosomal dominant leukodystrophy [37].

The overexpression of lamin A does not produce significant growth of the NE but results in local reorganization of the NE, in particular, the formation of protrusions from the nuclear surface (nuclear blebs), were observed in cells overexpressing lamin A [35]. Importantly, nuclei of prostate cancer cells and some other cancer types contain nuclear blebs enriched in lamin $\mathrm{A} / \mathrm{C}$ but deficient in lamin $\mathrm{B}[38,39]$.

The overexpression of two transmembrane nucleoporins, $\mathrm{Ndc} 1$ and Pom121, produces formation of cytoplasmic aggregates of membrane tubules [35]. Any tubular structures are characterized by the presence of strong membrane bending, therefore one can assume that these nucleoporins either induce membrane bending or recruit proteins that bend membranes. It is important to note that Ndc1 [40-43] and Pom121 [44-46] play an important role in the de novo formation of new pore complexes, a process also conjugated with membrane bending.

Additionally, the structural organization of the NE might be affected not only by changing protein concentration but also by the changing the ability of proteins to interact with each other.

Recently, the role of protein SUN1 was demonstrated in the development of Hutchinson-Gilford progeria syndrome, a disease associated with a mutation of lamin A [47]. Mutant lamin A (progerin) has a high affinity for SUN1, leading to aberrant recruitment of progerin to the ER membranes during postmitotic assembly of the nuclear envelope. The dysregulated interaction of SUN1 and progerin during the NE reformation contributes to nuclear aberrancies typical to HutchinsonGilford progeria syndrome. This is a consequence of local but not total increases in protein concentration due to enhanced affinity of the protein to a structure at the moment of its formation.

Intranuclear membrane structures. INM can form small protrusions inside the nucleus [35]. Additionally, inside the nuclei of some tumor cells, compact clusters of membrane tubules have been described [48]. The functional significance of these intranuclear protrusions and intranuclear tubular complexes are currently unknown. Such structures are formed in large quantities after lamin A overexpression, particularly following the nucleoporin Pom121 overexpression [35]. Moreover, following the Pom121 overexpression, some cells were observed to contain globules with increased amounts of this protein within the nucleus. Using correlative light and electron microscopy, these complexes have been shown to be formed by membranes representing protrusions of the INM. Besides, such hypertrophic INM protrusions have been described to form nucleolar channel system $[49,50]$. The nucleolar channel system consists of a set of intranuclear clusters of membrane tubules, which are located near the nuclear envelope or nucleoli. Such structures are identified in endometrial cells on 16-24 days of the menstrual cycle. The nucleolar channel system formation is induced by progesterone [51, 52]

Intranuclear membrane structures can be induced by the nucleolar protein Nopp140 [53] as well as proteins of NE. Following protein overexpression, intranuclear Nopp140-containing globules (R-rings) are observed. These complexes are formed by concentrically packed membranes which contain ER-specific membrane proteins. The morphology of these complexes and their proteins are very similar to those in the nucleolar channel system. In particular, both structures contain Nopp 140 , which may be the major component that induces biogenesis of R-rings and of the nucleolar channel system [53]. Afterwards, it was also demonstrated that the formation of this system is complex and depends on another as yet unidentified protein [54]. Morphologically similar intranuclear membrane complexes have been observed in cells after prelamin A accumulation [55], overexpression of nucleoporin Nup153 [56], and lamin B2 [57].

The mechanisms of INM protrusion growth are poorly understood. The simplest assumption is that they form as a compensatory response to abundant formation 
of INM (similar to the formation of NE invaginations after lamin B1 overexpression). However, it should be noted that the Pom121-induced protrusions are formed only after the cell passes through mitosis, i. e., as a pathological response to the post-mitotic NE formation [35].

The NE of metazoan cells completely disintegrates during cell division to allow the mitotic spindle to access chromosomes. During mitosis, the majority of soluble NE proteins are distributed throughout the cytoplasm and transmembrane NE proteins reside in the mitotic ER [58-60]. It is important that membrane components are absent in the zone occupied by the mitotic spindle. It seems that the removal of membrane vesicles from the mitotic spindle determines the absence of membrane structures within the nuclei. It has been shown that the mitotic phosphorylation of the ER protein STIM1 is responsible for the dissociation of membrane vesicles from microtubules [61]. Non-phosphorylatable STIM1 leads to faulty localization of ER vesicles in mitosis, with vesicles localized inside the mitotic spindle. Additionally, the ER protein REEP3/4 was identified as having the ability to bind microtubules [62]. Depletion of this protein leads to the accumulation of ER vesicles on the surface of chromosomes, which in turn leads to the formation of intranuclear membrane structures in postmitotic cells [62]. Unfortunately, the nature of these structures has not been described, due to an absence of electron microscopic data. However, the results of these studies suggest that alterations of post-mitotic biogenesis of the NE may be a possible mechanism underlying the formation of intranuclear membrane structures.

The endoplasmic reticulum. ER is a highly dynamic cellular compartment, and its organization differs between cell types. In cultured cells, ER forms a network of membrane structures defined as either ribosome-covered (rough ER) or ribosome-free (smooth ER). The ER components can be divided into two distinct morphological types, cisternae and tubules, which are the major components of rough and smooth ER, respectively. ER is able to change its structural organization depending on the physiological state of the cell. A classic example of the fast reorganization of ER is the development of a smooth ER system in cells in response to phenobarbital [63].

The structural organization of ER and the possibility of structural transitions between different forms of ER depend on reticulons and DP1/Yop1p proteins, which are responsible for the formation of ER tubules, i.e., ER components with highly curved membranes [64]. These proteins specifically act to induce curvature by inserting into the outer leaflet of the membrane [65]. The overexpression of certain reticulon proteins leads to the assembly of long tubules, whereas the absence of both reticulons and Yop1p in yeast leads to the loss of tubular ER [64]. Importantly, these proteins are excluded from ER sheets and NE, which may be considered as a flat ER sheet; however, reticulons have been shown to be involved in NPC assembly, most likely through the creation of a NE pore [66, 67].

Plasticity of endoplasmic reticulum. The nuclear membrane is an integral structural part of ER, which in turn is structurally and functionally closely associated with the Golgi complex. For a long time, both the Golgi and ER were considered stable structures; however, observations of live cells have demonstrated that the material in these compartments are constantly and rapidly exchanged [68], so that this macroscopically stable structure is formed by dynamic components. Morphological organization of ER and the Golgi complex depends on the balance of inflow and outflow components. For example, inhibition of the component inflow from ER leads to disassembly of the Golgi complex [69].

In cultured cells, ER forms a network of branching tubular structures and cisternae. In some situations, this network may be partially transformed into the so-called organized smooth ER (OSER), which may have different morphologies but is always characterized by an ordered packing of the membranes. Such structures are described after treatment with toxic substances [7072]. Of particular interest is the fact that OSER can be formed after overexpression of certain proteins of the ER and NE [72-79].

OSER formation can be caused by dynamic interactions between cytoplasmic domains of the membrane proteins [78]. Some proteins cannot induce OSER formation but are able to form homodimers after fusion of the cytosolic domain with either GFP or YFP and gain the ability to induce the formation of OSER [78, 80]. This has been exploited to assess the tendency of fluorescent proteins to oligomerize under physiologic conditions [81]. 
The interactions leading to the reorganization of ER and formation of OSER have been shown to be weak thus cytochrome $b(5)$ demonstrated a lateral mobility in the membrane and is able to move freely inside and between OSER and the rest of the ER [78]. Some proteins of the nuclear envelope are capable of inducing reorganization of the ER network. Expression of the INM protein, Lap2 $\beta$, leads to the development of OSER complexes formed with numerous tightly packed ER membranes [79]. Despite the high packing density of the membranes, Lap2 $\beta$ retained high lateral mobility. Low lateral mobility was described for YFP-tagged langerin, a protein required for the biogenesis of Birbeck granules, the characteristic organelles of Langerhans cells [80]. However, in this case, the formation of OSER was caused by the YFP oligomerization.

The OSER formation may be induced by the overexpression of different proteins, suggesting that this process is nonspecific. Moreover, there are some similarities between these complexes and intranuclear membrane complexes. Neither of these structures result from a compensatory response; instead, they result from the ability of abundant proteins to induce an excessive membrane modification (bending, collapse, stacking, etc.). Such membrane structures may be formed by the action of membrane proteins that have lost their ability to be exported from the ER due to mutation. Such pathological phenotypes, in particular, have been observed in a mouse model of Charcot-Marie-Tooth disease [82] and torsion dystonia [83].

Nucleoporins are localized not only in NE but also in the cytoplasmic stacks of membrane cisternae pierced by numerous pore complexes. Such complexes are called annulate lamellae (AL). AL have been described in the cytoplasm of a wide variety of cells, notably in oocytes, embryonic cells, and rapidly dividing cells including many types of tumor cells. Prolonged exposure to sublethal doses of the antimitotic drugs colchicine and vinblastine sulfate induces AL in diverse cell types and species [84]. AL are rarely found in the nucleoplasm, for example, in rat trophoblast cells at the definitive stage of differentiation [85].

Over the years, a variety of roles have been ascribed to AL [84], with the prevalent consensus that AL are stockpiles of excess nucleoporins that support subsequent, rapid cell divisions. In support of this theory, the major fraction of the nucleoporin Nup62 is localized inside AL [86] in Xenopus stage VI oocytes. However, in Drosophila embryos, AL have only a minor role in storing excess maternally contributed nucleoporins [87]. This is indicative of the fact that AL have functions unrelated to the preservation of excess nucleoporins, such as changing ER properties. In particular, it was shown that NPCs within AL suppress local $\mathrm{Ca}^{2+}$ signaling activity of the ER [88].

The expression of individual proteins normally does not lead to the appearance of additional AL. The only example of such induction was described for Pom121overexpressing cells [89]. However, using correlative light and electron microscopy, it was demonstrated that Pom121-containing cytoplasmic complexes are formed by membrane tubules and do not contain NPCs, i. e., they are not AL [35]. In this regard, it should be noted that some reports indicate AL do not contain Pom121 [90].

Conclusions. NE and ER demonstrate high structural plasticity and the ability to vary according to the physiological conditions and during the development of pathological processes. Heterogeneity in the organization of these structures may depend on changes in the global or local concentrations of the individual components. This has been confirmed with numerous data showing changes in membrane structures following overexpression of NE and ER proteins. The available data suggest that both NE and ER demonstrate an apparent structural plasticity, leading to physiological cell adaptation to changes in the external environment, specialized functions in differentiated cells or the development of pathological processes.

Funding. This work was supported by the Russian Foundation for Basic Research (grants 12-04-01237 and 14-04-01650) and the Russian Science Foundation (project 14-15-00199).

Структурна пластичність ядерної оболонки і

ендоплазматичного ретикулуму

Є. В. Шеваль, Я. Р. Мусинова

\section{Резюме}

Ядерна оболонка - двомембранна структура, неперервна з ендоплазматичним ретикулумом, причому морфологічна організація цих структур досить консервативна. Однак для ядерної оболонки i ендоплазматичного ретикулуму характерна виражена струк- 
турна пластичність, тобто на основі спільної організацї в клітинах можуть формуватися різні неканонічні структури, які виявляються або в спеціалізованих клітинах, або за розвитку деяких патологій. У представленому огляді розглянуто механізми біогенезу подібних неканонічних структур, а також можливу роль структурної пластичності у розвитку патологічних процесів.

Ключові слова: ядерна оболонка, ендоплазматичний ретикулум, структурна пластичність.

Структурная пластичность ядерной оболочки и эндоплазматического ретикулума

Е. В. Шеваль, Я. Р. Мусинова

Резюме

Ядерная оболочка - двухмембранная структура, непрерывная с эндоплазматическим ретикулумом, причем морфологическая организачия этих структур достаточно консервативна. Однако для ядерной оболочки и эндоплазматического ретикулума характерна выраженная структурная пластичность, m. е. на основе общей организации в клетках могут формироваться различные неканонические структуры, выявляющиеся либо в специализированных клетках, либо при развитии некоторых патологий. В настоящем обзоре рассмотрены механизмы биогенеза подобных неканонических структур, а также возможная роль структурной пластичности в развитии патологических процессов.

Ключевые слова: ядерная оболочка, эндоплазматический ретикулум, структурная пластичность

\section{REFERENCES}

1. Schirmer EC, Gerace L. The nuclear membrane proteome: extending the envelope. Trends Biochem Sci. 2005;30(10):551-8.

2. Korfali N, Wilkie GS, Swanson SK, et al. The leukocyte nuclear envelope proteome varies with cell activation and contains novel transmembrane proteins that affect genome architecture. $\mathrm{Mol}$ Cell Proteomics. 2010;9(12):2571-85.

3. Korfali N, Wilkie GS, Swanson SK, et al. The nuclear envelope proteome differs notably between tissues. Nucleus. 2012;3(6): 552-64.

4. Floch $A G$, Palancade B, Doye $V$. Fifty years of nuclear pores and nucleocytoplasmic transport studies: multiple tools revealing complex rules. Methods Cell Biol. 2014;122:1-40.

5. Loschberger A, Franke C, Krohne G, et al. Correlative super-resolution fluorescence and electron microscopy of the nuclear pore complex with molecular resolution. J Cell Sci. 2014. pii: jcs. 156620 .

6. Alber F, Dokudovskaya S, Veenhoff LM, et al. The molecular architecture of the nuclear pore complex. Nature. 2007;450 (7170): 695-701.

7. Niepel M, Molloy KR, Williams R, et al. The nuclear basket proteins Mlp1p and Mlp2p are part of a dynamic interactome including Esclp and the proteasome. Mol Biol Cell. 2013;24(24): 3920-38.

8. Tamura K, Fukao Y, Iwamoto $M$, et al. Identification and characterization of nuclear pore complex components in Arabidopsis thaliana. Plant Cell. 2010;22(12):4084-97.

9. Tamura K, Hara-Nishimura I. Involvement of the nuclear pore complex in morphology of the plant nucleus. Nucleus. 2011;2(3): 168-72.

10. Lidsky $P V$, Hato $S$, Bardina $M V$, et al. Nucleocytoplasmic traffic disorder induced by cardioviruses. J Virol. 2006;80(6):2705-17.
11. Bardina $M V$, Lidsky $P V$, Sheval EV, et al. Mengovirus-induced rearrangement of the nuclear pore complex: hijacking cellular phosphorylation machinery. J Virol. 2009;83(7):3150-61.

12. D'Angelo MA, Raices $M$, Panowski SH, Hetzer MW. Age-dependent deterioration of nuclear pore complexes causes a loss of nuclear integrity in postmitotic cells. Cell. 2009;136(2):284-95.

13. Johnson DC, Baines JD. Herpesviruses remodel host membranes for virus egress. Nat Rev Microbiol. 2011;9(5):382-94.

14. Mettenleiter TC, Muller F, Granzow H, Klupp BG. The way out: what we know and do not know about herpesvirus nuclear egress. Cell Microbiol. 2013;15(2):170-8.

15. Speese SD, Ashley J, Jokhi V, et al. Nuclear envelope budding enables large ribonucleoprotein particle export during synaptic Wnt signaling. Cell. 2012;149(4):832-46.

16. Heitlinger E, Peter $M$, Haner $M$, et al. Expression of chicken lamin B2 in Escherichia coli: characterization of its structure, assembly, and molecular interactions. J Cell Biol. 1991;113(3): 485-95.

17. Stuurman $N$, Sasse B, Fisher PA. Intermediate filament protein polymerization: molecular analysis of Drosophila nuclear lamin head-to-tail binding. J Struct Biol. 1996;117(1):1-15.

18. Ben-Harush K, Wiesel N, Frenkiel-Krispin D, et al. The supramolecular organization of the $C$. elegans nuclear lamin filament. J Mol Biol. 2009;386(5):1392-402.

19. Stewart $C$, Burke B. Teratocarcinoma stem cells and early mouse embryos contain only a single major lamin polypeptide closely resembling lamin B. Cell. 1987;51(3):383-92.

20. Yang SH, Jung HJ, Coffinier C, et al. Are B-type lamins essential in all mammalian cells? Nucleus. 2011;2(6):562-9.

21. Kim Y, Sharov AA, McDole K, et al. Mouse B-type lamins are required for proper organogenesis but not by embryonic stem cells. Science. 2011;334(6063):1706-10.

22. Swift J, Ivanovska IL, Buxboim A, et al. Nuclear lamin-A scales with tissue stiffness and enhances matrix-directed differentiation. Science. 2013;341(6149):1240104.

23. Constantinescu D, Gray HL, Sammak PJ, Schatten GP, Csoka $A B$. Lamin $\mathrm{A} / \mathrm{C}$ expression is a marker of mouse and human embryonic stem cell differentiation. Stem Cells. 2006;24(1):177-85.

24. Legartova S, Stixova L, Laur $O$, et al. Nuclear structures surrounding internal lamin invaginations. J Cell Biochem. 2014;115(3): 476-87.

25. Kaufmann SH, Mabry M, Jasti R, Shaper JH. Differential expression of nuclear envelope lamins $\mathrm{A}$ and $\mathrm{C}$ in human lung cancer cell lines. Cancer Res. 1991;51(2):581-6.

26. Broers $J L$, Raymond $Y$, Rot MK, et al. Nuclear A-type lamins are differentially expressed in human lung cancer subtypes. Am J Pathol. 1993;143(1):211-20.

27. Machiels BM, Broers JL, Raymond Y, et al. Abnormal A-type lamin organization in a human lung carcinoma cell line. Eur J Cell Biol. 1995;67(4):328-35.

28. Belt EJ, Fijneman RJ, van den Berg EG, et al. Loss of lamin A/C expression in stage II and III colon cancer is associated with disease recurrence. Eur J Cancer. 2011;47(12):1837-45.

29. Moss SF, Krivosheyev V, de Souza A, et al. Decreased and aberrant nuclear lamin expression in gastrointestinal tract neoplasms. Gut. 1999;45(5):723-9.

30. $W u Z, W u L$, Weng $D$, et al. Reduced expression of lamin A/C correlates with poor histological differentiation and prognosis in primary gastric carcinoma. J Exp Clin Cancer Res. 2009;28:8.

31. Capo-chichi CD, Cai KQ, Smedberg J, et al. Loss of A-type lamin expression compromises nuclear envelope integrity in breast cancer. Chin J Cancer. 2011;30(6):415-25. 
32. Wazir U, Ahmed MH, Bridger JM, et al. The clinicopathological significance of lamin $\mathrm{A} / \mathrm{C}$, lamin $\mathrm{B} 1$ and lamin $\mathrm{B}$ receptor mRNA expression in human breast cancer. Cell Mol Biol Lett. 2013; 18(4):595-611.

33. Agrelo R, Setien F, Espada J, et al. Inactivation of the lamin A/C gene by $\mathrm{CpG}$ island promoter hypermethylation in hematologic malignancies, and its association with poor survival in nodal diffuse large B-cell lymphoma. J Clin Oncol. 2005;23(17):3940-7.

34. Prufert $K$, Vogel A, Krohne $G$. The lamin CxxM motif promotes nuclear membrane growth. J Cell Sci. 2004;117(Pt 25):6105-16.

35. Volkova EG, Kurchashova SY, Polyakov VY, Sheval EV. Selforganization of cellular structures induced by the overexpression of nuclear envelope proteins: a correlative light and electron microscopy study. J Electron Microsc (Tokyo). 2011; 60 (1):57-71.

36. Brandt A, Krohne G, Grosshans $J$. The farnesylated nuclear proteins KUGELKERN and LAMIN B promote aging-like phenotypes in Drosophila flies. Aging Cell. 2008;7(4):541-51.

37. Padiath QS, Saigoh K, Schiffmann R, et al. Lamin B1 duplications cause autosomal dominant leukodystrophy. Nat Genet 2006;38(10):1114-23.

38. Helfand BT, Wang Y, Pfleghaar $K$, et al. Chromosomal regions associated with prostate cancer risk localize to lamin B-deficient microdomains and exhibit reduced gene transcription. J Pathol. 2012;226(5):735-45.

39. Funkhouser CM, Sknepnek R, Shimi T, et al. Mechanical model of blebbing in nuclear lamin meshworks. Proc Natl Acad Sci USA. 2013;110(9):3248-53.

40. Stavru F, Hulsmann BB, Spang A, et al. NDC1: a crucial membrane-integral nucleoporin of metazoan nuclear pore complexes. J Cell Biol. 2006;173(4):509-19.

41. Mansfeld J, Guttinger S, Hawryluk-Gara LA, et al. The conserved transmembrane nucleoporin NDC1 is required for nuclear pore complex assembly in vertebrate cells. Mol Cell. 2006;22 (1):93-103.

42. Madrid AS, Mancuso J, Cande WZ, Weis K. The role of the integral membrane nucleoporins Ndc1p and Pom152p in nuclear pore complex assembly and function. J Cell Biol. 2006;173(3): $361-71$.

43. Onischenko E, Stanton LH, Madrid AS, et al. Role of the Ndc1 interaction network in yeast nuclear pore complex assembly and maintenance. J Cell Biol. 2009;185(3):475-91.

44. Antonin W, Franz C, Haselmann U, et al. The integral membrane nucleoporin pom 121 functionally links nuclear pore complex assembly and nuclear envelope formation. Mol Cell. 2005;17 (1):83-92

45. Doucet CM, Talamas JA, Hetzer MW. Cell cycle-dependent differences in nuclear pore complex assembly in metazoa. Cell. 2010;141(6):1030-41.

46. Funakoshi T, Clever M, Watanabe A, Imamoto N. Localization of Pom121 to the inner nuclear membrane is required for an early step of interphase nuclear pore complex assembly. Mol Biol Cell. 2011;22(7):1058-69.

47. Chen ZJ, Wang WP, Chen YC, et al. Dysregulated interactions between lamin A and SUN1 induce abnormalities in the nuclear envelope and endoplasmic reticulum in progeric laminopathies. J Cell Sci. 2014;127(Pt 8):1792-804.

48. Caruso RA, Rigoli L, Fedele F, et al. Modifications of nuclear envelope in tumour cells of human gastric carcinomas: an ultrastructural study. Anticancer Res. 2010;30(2):699-702.

49. Clyman MJ. A new structure observed in the nucleolus of the human endometrial epithelial cell. Am J Obstet Gynecol. 1963;86: $430-2$.
50. Terzakis JA. The nucleolar channel system of human endometrium. J Cell Biol. 1965;27(2):293-304

51. Kohorn EI, Rice SI, Gordon M. In vitro production of nucleolar channel system by progesterone in human endometrium. Nature. 1970;228(5272):671-2.

52. Nejat EJ, Szmyga MJ, Zapantis G, Meier UT. Progesterone threshold determines nucleolar channel system formation in human endometrium. Reprod Sci. 2014;21(7):915-920.

53. Isaac C, Pollard JW, Meier UT. Intranuclear endoplasmic reticulum induced by Nopp 140 mimics the nucleolar channel system of human endometrium. $J$ Cell Sci. 2001;114(Pt 23):4253-64.

54. Kittur N, Zapantis G, Aubuchon M, et al. The nucleolar channel system of human endometrium is related to endoplasmic reticulum and R-rings. Mol Biol Cell. 2007;18(6):2296-304.

55. Goulbourne CN, Malhas AN, Vaux DJ. The induction of a nucleoplasmic reticulum by prelamin A accumulation requires CTP: phosphocholine cytidylyltransferase? J Cell Sci. 2011;124(Pt 24): 4253-66.

56. Bastos R, Lin A, Enarson M, Burke B. Targeting and function in mRNA export of nuclear pore complex protein Nup153. $J$ Cell Biol. 1996;134(5):1141-56.

57. Linde N, Stick R. Intranuclear membranes induced by lipidated proteins are derived from the nuclear envelope. Nucleus. 2010;1 (4):343-53.

58. Ellenberg J, Siggia ED, Moreira JE, et al. Nuclear membrane dynamics and reassembly in living cells: targeting of an inner nuclear membrane protein in interphase and mitosis. J Cell Biol. 1997;138(6): 1193-206

59. Anderson DJ, Hetzer $M W$. Nuclear envelope formation by chromatin-mediated reorganization of the endoplasmic reticulum. Nat Cell Biol. 2007;9(10):1160-6.

60. Puhka M, Vihinen H, Joensuu M, Jokitalo E. Endoplasmic reticulum remains continuous and undergoes sheet-to-tubule transformation during cell division in mammalian cells. $J$ Cell Biol. 2007;179(5):895-909.

61. Smyth JT, Beg AM, Wu S, et al. Phosphoregulation of STIM1 leads to exclusion of the endoplasmic reticulum from the mitotic spindle. Curr Biol. 2012;22(16):1487-93.

62. Schlaitz AL, Thompson J, Wong CC, et al. REEP3/4 ensure endoplasmic reticulum clearance from metaphase chromatin and proper nuclear envelope architecture. Dev Cell. 2013;26(3):315-23.

63. Orrenius $S$, Ericsson JL. On the relationship of liver glucose-6phosphatase to the proliferation of endoplasmic reticulum in phenobarbital induction. $J$ Cell Biol. 1966;31(2):243-56.

64. Voeltz GK, Prinz WA, Shibata Y, et al. A class of membrane proteins shaping the tubular endoplasmic reticulum. Cell. 2006;124 (3):573-86.

65. Zimmerberg J, Kozlov MM. How proteins produce cellular membrane curvature. Nat Rev Mol Cell Biol. 2006;7(1):9-19.

66. Antonin W, Ellenberg J, Dultz E. Nuclear pore complex assembly through the cell cycle: regulation and membrane organization. FEBS Lett. 2008;582(14):2004-16.

67. Dawson TR, Lazarus MD, Hetzer MW, Wente SR. ER membrane-bending proteins are necessary for de novo nuclear pore formation. J Cell Biol. 2009;184(5):659-75.

68. Lippincott-Schwartz J, Roberts TH, Hirschberg K. Secretory protein trafficking and organelle dynamics in living cells. Annu Rev Cell Dev Biol. 2000;16:557-89.

69. Zaal KJ, Smith CL, Polishchuk RS, et al. Golgi membranes are absorbed into and reemerge from the ER during mitosis. Cell. 1999;99(6):589-601.

70. Chin DJ, Luskey KL, Anderson RG, et al. Appearance of crystalloid endoplasmic reticulum in compactin-resistant Chinese hamster cells with a 500-fold increase in 3-hydroxy-3-methylglutaryl- 
coenzyme A reductase. Proc Natl Acad Sci USA. 1982;79(4): $1185-9$.

71. Singer II, Scott S, Kazazis DM, Huff JW. Lovastatin, an inhibitor of cholesterol synthesis, induces hydroxymethylglutaryl-coenzyme A reductase directly on membranes of expanded smooth endoplasmic reticulum in rat hepatocytes. Proc Natl Acad Sci USA. 1988;85(14):5264-8.

72. Berciano MT, Fernandez R, Pena E, et al. Formation of intranuclear crystalloids and proliferation of the smooth endoplasmic reticulum in schwann cells induced by tellurium treatment: association with overexpression of HMG CoA reductase and HMG CoA synthase mRNA. Glia. 2000;29(3):246-59.

73. Wright R, Keller G, Gould SJ, et al. Cell-type control of membrane biogenesis induced by HMG-CoA reductase. New Biol. 1990; 2(10):915-21.

74. Takei K, Mignery GA, Mugnaini E, et al. Inositol 1,4,5-trisphosphate receptor causes formation of ER cisternal stacks in transfected fibroblasts and in cerebellar Purkinje cells. Neuron. 1994; 12(2):327-42.

75. Ohkuma M, Park SM, Zimmer T, et al. Proliferation of intracellular membrane structures upon homologous overproduction of cytochrome P-450 in Candida maltosa. Biochim Biophys Acta. 1995; 1236(1):163-9.

76. Yamamoto A, Masaki R, Tashiro Y. Formation of crystalloid endoplasmic reticulum in COS cells upon overexpression of microsomal aldehyde dehydrogenase by cDNA transfection. $J$ Cell Sci. 1996;109 (Pt 7):1727-38.

77. Sandig G, Kargel E, Menzel R, et al. Regulation of endoplasmic reticulum biogenesis in response to cytochrome P450 overproduction. Drug Metab Rev. 1999;31(2):393-410.

78. Snapp EL, Hegde RS, Francolini M, et al. Formation of stacked ER cisternae by low affinity protein interactions. $J$ Cell Biol. 2003;163(2):257-69.

79. Volkova EG, Abramchuk SS, Sheval EV. The overexpression of nuclear envelope protein Lap2 $\beta$ induces endoplasmic reticulum reorganisation via membrane stacking. Biol Open. 2012;1(8): $802-5$.
80. Lenormand C, Spiegelhalter C, Cinquin B, et al. Birbeck granulelike «organized smooth endoplasmic reticulum» resulting from the expression of a cytoplasmic YFP-tagged langerin. PLoS One. 2013;8(4):e60813.

81. Costantini LM, Fossati M, Francolini M, Snapp EL. Assessing the tendency of fluorescent proteins to oligomerize under physiologic conditions. Traffic. 2012;13(5):643-9.

82. Dickson KM, Bergeron JJ, Shames I, et al. Association of calnexin with mutant peripheral myelin protein-22 ex vivo: a basis for «gain-of-function» ER diseases. Proc Natl Acad Sci USA. 2002; 99(15):9852-7.

83. Hewett J, Gonzalez-Agosti C, Slater D, et al. Mutant torsinA, responsible for early-onset torsion dystonia, forms membrane inclusions in cultured neural cells. Hum Mol Genet. 2000;9(9):1403-13.

84. Kessel RG. Annulate lamellae: a last frontier in cellular organelles. Int Rev Cytol. 1992;133:43-120.

85. Zybina EV, Zybina TG. Modifications of nuclear envelope during differentiation and depolyploidization of rat trophoblast cells. Micron. 2008;39(5):593-606.

86. Cordes VC, Reidenbach $S$, Franke $W W$. High content of a nuclear pore complex protein in cytoplasmic annulate lamellae of Xenopus oocytes. Eur J Cell Biol. 1995;68(3):240-55.

87. Onischenko EA, Gubanova NV, Kieselbach T, et al. Annulate lamellae play only a minor role in the storage of excess nucleoporins in Drosophila embryos. Traffic. 2004;5(3):152-64.

88. Boulware MJ, Marchant JS. Nuclear pore disassembly from endoplasmic reticulum membranes promotes $\mathrm{Ca}^{2+}$ signalling competency. $J$ Physiol. 2008;586(Pt 12):2873-88.

89. Daigle N, Beaudouin J, Hartnell L, et al. Nuclear pore complexes form immobile networks and have a very low turnover in live mammalian cells. J Cell Biol. 2001;154(1):71-84.

90. Ewald A, Kossner U, Scheer U, Dabauvalle MC. A biochemical and immunological comparison of nuclear and cytoplasmic pore complexes. J Cell Sci. 1996;109 (Pt 7):1813-24.

Received 30.06.14 